Title:

Parent and Adolescent Perceptions of Adolescent Career Development Tasks and Vocational Identity

Authors:

Mary E. Rogers ${ }^{1}$, Peter A. Creed $^{2}$, and Anna Praskova ${ }^{2}$

Author Affiliations:

${ }^{1}$ Griffith University, Griffith Business School, Department of Employment Relations and Human Resources, and Centre for Work, Organisation and Wellbeing

${ }^{2}$ Griffith University, School of Applied Psychology and Menzies Health Institute Queensland

Corresponding Author: $\quad$ Dr Mary Rogers Griffith University

Griffith Business School, Department of Employment Relations and Human Resources

Gold Coast Campus, QLD, 4222, Australia.

Telephone: $\quad$ +61755527070

Facsimile: +61755529206

Author Email Addresses: $\quad$ mary.rogers@griffith.edu.au p.creed@griffith.edu.au a.praskova@griffith.edu.au 


\title{
Parent and Adolescent Perceptions of Adolescent Career Development Tasks and Vocational Identity
}

\begin{abstract}
We tested differences and overlap in adolescent and parent perceptions of adolescent career development tasks (career planning, exploration, certainty, and world-of-work knowledge) and vocational identity. We found that, for adolescents $(N=415)$, career development tasks (not career exploration) explained $48 \%$ of the variance in vocational identity; for parents $(N=$ 415) this was 38\% (not world-of-work knowledge). Parent perceptions of career development tasks did not explain additional variance in adolescent vocational identity. There were moderate correlations between adolescent and parent perceptions of career development tasks and vocational identity, suggesting meaningful, but not substantial, congruence of perceptions. The findings provide useful insights into the understanding of, and relationship between, parent and adolescent perceptions of adolescent career development tasks and vocational identity, which suggest avenues for interventions with adolescents and parents.
\end{abstract}

Keywords: adolescents; parent ratings; career development tasks; vocational identity. 


\section{Parent and Adolescent Perceptions of Adolescent Career Development Tasks and Vocational Identity}

Vocational identity is defined as having a clear, stable, and coherent picture of one's career interests, goals, and abilities (Holland, 1985), and reflects having developed a strong commitment to internalised career goals (Blustein, Ellis, \& Devenis, 1989; Meijers, 1998). Vocational identity starts to develop in childhood when children look to their parents for guidance and as role models, and becomes more developed, stable, and salient in adolescence when young people explore possible life directions and prepare for the transition from school to further education and work (Danielsen, Lorem, \& Kroger, 2000; Kroger, 2007). Engaging in career development tasks and forming a vocational identity are important aspects of adolescent career development and important indicators of identity development (Flum \& Blustein, 2006; Kroger, 2007; Skorikov \& Vondracek, 2011). While vocational identity in adolescence is influenced by parents and the family context (e.g., in relation to career exploration, planning, and decision making; Ketterson \& Blustein, 1997; Young et al., 1997), no known studies have assessed the congruence between parent and adolescent perceptions of career development tasks or vocational identity development. The purpose of this research was to (a) assess the relationship between career development tasks and vocational identity using both parent and adolescent samples, and (b) test the congruence between parent and adolescent perceptions of career development tasks and vocational identity development.

Important career developmental tasks for adolescents are to recognise interests, capacities, and values, acquire knowledge about work, and eventually decide upon realistic educational and career pathways (Super, 1990). When making career-related decisions, adolescents also need to adopt positive career attitudes and behaviours, and base their decisions on career-relevant knowledge and skills (e.g., occupational information that provides a level of career decision-making certainty; Super, 1990). Consistent with this, 
career construction theory (Savickas, 2002) proposed that the construction of a vocational identity relies on career exploration, planning, decision-making, and career confidence. This reflects the general consensus in the career literature that vocational identity develops through engagement in various career development tasks and is shaped by a range of personal and contextual factors (Creed \& Hennessey, in press; Flum \& Kaplan, 2006; Robitschek \& Cook, 1999; Skorikov \& Vondracek, 2011). Thus, the first objective of the present study was to assess the relationship between vocational identity and four career development tasks indicated by career construction (Savickas, 2002) and development (Flum \& Kaplan, 2006; Super, 1990) theories (operationalized as career exploration, career planning, world-of-work information, and career certainty), using samples of high school adolescents and their parents.

\section{Career Development Tasks}

Vocational identity is fostered by successful engagement in career development tasks and by adopting positive career attitudes (Kerpelman, Pittman, \& Lamke, 1997; Savickas, 2002; Super, 1990; Zikic \& Hall, 2009). Career exploration is a critical, adaptive, and lifelong process, which involves obtaining information about the self and occupations from various sources, such as parents, counsellors, teachers, and books, and attempting different roles and activities, which, in young people, are aimed at crystallising directions and facilitating making career decisions (Porfeli, Lee, \& Vondracek, 2013; Super, 1990). Career exploration is purposeful and goal directed, and carried out according to conscious and unconscious plans (Bandura, 1991).

Career planning is an important, life-long, motivational strategy in career development. It involves synthesising the information collected on the self and environment and using it to inform courses of action and time-lines. It reflects goal-oriented thinking and the development of specific behavioural paths to a career goal (Austin \& Vancouver, 1996; Phillips \& Blustein, 1994). Active career exploration and planning are associated with 
vocational identity in samples ranging from high school adolescents to young adults (Hirschi, Niles, \& Akos, 2011; Praskova, Creed, \& Hood, 2015; Robitschek \& Cook, 1999; Turner \& Lapan, 2002; Vondracek \& Skorikov, 1997).

In the process of career preparation, young people become more self-aware regarding their likes and dislikes (Zikic \& Hall, 2009), and are better equipped to make career decisions as they have acquired knowledge about possible educational and career choices, occupational roles, and the work environment in general (Nurmi, 1991; Super, 1990; Witko et al., 2005). This learning about the world-of-work is essential for effective career development because it supports the ability of adolescents to make informed, age-appropriate career decisions, and promotes the development of a clearer vocational identity (Savickas, 1999; Super, 1990; Trede, 2012). Adolescents typically obtain this information from discussions with parents and teachers, by consulting career resources, and drawing on other sources, such as work experience, part-time employment, and the media (Trede, 2012; Zimmer-Gembeck \& Mortimer, 2006).

There is less predictability and more competition in modern labour markets, which makes preparation for and actual transition from school to work more challenging for young people (Staff, Harris, Sabates, \& Briddell, 2010). Developing some certainty about one’s career choice, which represents a higher level of career maturity (Creed \& Patton, 2011), assists adolescents to cope with these challenges and promotes the development of vocational identity. Career decidedness, career choice self-efficacy (Gupta, Chong, \& Leong, 2015; Rojewski, 1994), and confidence orientation (an orientation associated mature decisionmaking; Robitschek \& Cook, 1999; Skorikov \& Vondracek, 2011), have all been shown to be associated positively with vocational identity. Specific to career certainty, adolescents who are more certain about their career choice report better occupational outcomes (Staff et al., 2010). Career certainty in young people is also associated with career maturity (Holland, 
Johnston, \& Asama, 1993), being the main predictor of career maturity in Australian high school students (Creed \& Patton, 2003). These results suggest that adolescents who are more certain about their career direction will also have a more well-developed vocational identity.

Based on this review, we expected that greater engagement in career exploration (H1a) and career planning (H1b), greater knowledge of world-of-work information (H1c), and greater career certainty (H1d) will be associated positively with adolescent vocational identity.

\section{Parental Influence and Congruence with Adolescent Children}

The career literature suggests that successful career development is influenced by a range of contextual factors (e.g., family, school, and peers), which can have both direct and indirect effects on the development of vocational identity (Kerpelman et al., 1997; Savickas, 2002; Skorikov \& Vondracek, 2011). An especially important contextual factor for career development and vocational identity is the family (Kerpelman et al., 1997; Skorikov \& Vondracek, 2011). Although the effects of family (e.g., support, guidance) and parental expectations (e.g., educational background, socio-economic status) on career development tasks and vocational identity have been supported previously (Hou \& Leung, 2011; Tucker, Barber, \& Eccles, 2001; Otto, 2000; Whiston \& Keller, 2004), there is limited research that has examined parent and adolescent perceptions concurrently. Having reports from both parties has the potential to yield important information for designing and evaluating career educational programs to assist young people who are struggling with their career development (Stice \& Barrera, 1995).

Based on limited career-relevant research, the level of congruence between parents and their adolescent offspring regarding the adolescent's vocational identity markers should be high. Parents are in day-to-day contact with their children, have the opportunity to observe their development, and can discuss with them their career and educational progress. Thus, 
parents should be well-informed about their child's career development activities and general vocational identity development. Support for this comes from studies that have shown that adolescents first ask their parents for help when deciding on important developmental milestones, such as setting educational goals and selecting a career path (Witko, Bernes, Magnusson, \& Bardick, 2005), and that parents shape their children’s career development experiences (Jodl, Michael, Malanchuk, Eccles, \& Sameroff, 2001; Savickas, 2002).

While adolescents express their own agency, career development evolves within social networks and societal expectations that shape their career self-concept, attitudes, and aspirations (e.g., via conversations with others, observation and modelling, and identifying with current practices; Bandura, 1991; Savickas, 2002; Trede, 2012; Vondracek, Lerner, \& Schulenberg, 1986). Parents especially play an important role in their child's career development by utilising different channels to communicate their expectations about their career choices (Hou \& Leung, 2011; Kerpelman et al., 1997). For example, parents will communicate directly with their child about careers and education, provide career guidance and direction, encourage autonomy and responsibility, and actively get involved in their broader lives (Young, Friesen, \& Dillabough, 1991).

Adolescents also learn career-relevant attitudes, behaviours, and skills indirectly from their parents during childhood and early adolescence, based on the expectations modelled by parents and the information they provide (Julien, 1999). Adolescents, for example, gain confidence from modelling on parents (Alliman-Brissett, Turner, \& Skovholt, 2004) and adopt parent work and education values and aspirations (Jodl et al., 2001; Wettersten et al., 2005). Parental support is associated with adolescent career and educational attitudes, expectations to attend university (Wettersten et al., 2005), career decision self-efficacy, and career certainty (Constantine, Wallace, \& Kindaichi, 2005; Gushe \& Whitson, 2006), and career exploration (Rogers \& Creed, 2011; Rogers, Creed, \& Glendon, 2008). 
From the above, it can be said that parents are one of the main socialisers of children's career attitudes and vocational identity, reflecting that parental expectations and views are manifested in their child's self-perceptions and career/educational choices (Jodl et al., 2001). This suggests that the perceptions of career development tasks and vocational identity held by parents and their children should be congruent (i.e., the two perspectives should agree regarding career development tasks and vocational identity development). To our knowledge, no study has assessed this congruence, although the literature suggests that information from multiple reporters provides more useful data as these can enhance understandings of development (Pelegrina, García-Linares, \& Casanova, 2003). Specifically, when assessing vocational identity standards, Kerpelman et al. (1997) recommended collecting matching data from parents and adolescents, as both are involved in the identity development process.

Few studies have collected career-related data simultaneously from both parents and their adolescent children. Hou and Leung (2011) compared the perceptions of career aspirations of parents and their adolescent children across the six Holland occupational fields and found that the parental expectation/adolescent aspiration gap was relatively small. However, Malmberg, Ehrman, and Lithén (2005) reported that parent and adolescent ratings on beliefs about the adolescent's career goals, and the probability of success of those goals, were unrelated. These results suggest that there might be congruence at the broad career (e.g., Realistic, Investigative, Artistic, Social, Enterprising, Conventional) theme level, but not at the more detailed goal level; however, more detailed research is required.

We identified no study that assessed congruence between parent and adolescent perceptions of career development tasks and vocational identity, which reflects an important gap in the career literature. Thus, the second goal of our study was to assess this congruence. Based on the above literature, we expected that (H2a) parents and adolescents would hold similar views regarding career development tasks and vocational identity (i.e., parent- 
adolescent correlations on career development variables and vocational identity would be significant and positive), that (H2b) parent and adolescent ratings on career development tasks would be similarly related to the perceived vocational identity of the adolescent, and that (H2c) parent understanding of their adolescent child’s career development tasks would help explain adolescent vocational identity. See Figure 1.

\section{Method}

\section{Participants}

We surveyed 1,711 high school students and asked them to take a form home for their parents to complete. We received 568 completed questionnaires from parents (response rate $33.2 \%$; although we had no way of knowing if all adolescents took the parent questionnaire home with them or that all completed parent forms were returned by the adolescents). Of these responses, we identified 415 sets of useable surveys (i.e., parent plus child matched pair). Thus, participants were 415 high school adolescents (55\% female; mean age 16.28 years; $S D=.89$ ) and 415 parents or guardians of these adolescents (one parent/guardian per adolescent: $82 \%$ mothers, $18 \%$ fathers, and .4\% guardians). The adolescents were in grades 10 (43\%), 11 (35\%), and 12 (22\%) at co-educational, middle level SES schools (31\% public school, 69\% private school) in a large regional centre in South East Queensland, Australia. Almost all students were Caucasian and identified as being Australian, which is typical of high school populations in Australia where there are no large racial or ethnic groupings common in other countries.

\section{Measures}

Adolescents and parents completed the same survey, except that adolescents were asked to respond in relation to themselves, and parents were asked to respond in relation to their adolescent child. On all scales, higher scores reflect higher levels of the construct. 
Vocational identity. Consistent with the view (Blustein, Ellis \& Devenis, 1989; Meijers, 1998) and supporting empirical evidence (Blustein, Devenis, \& Kidney, 1989; Blustein, Pauling, De Mania, \& Faye, 1994) that vocational identity reflects the development of a strong attachment or commitment to internalised career goals, we used a 6-item scale (Mu, 1998) to assess this aspect of vocational identity. Sample items were: "I know what I want to do in terms of an occupation or career/My son/daughter knows what they want to do in terms of an occupation or career" and "I believe I will be able to achieve my occupational /career goals/My son/daughter believes they will be able to achieve their occupational /career goals”. Responses were indicated on a 4-point Likert-like scale ( 1 = strongly disagree to $4=$ strongly agree). Previous reported reliability for the scale has been high $(\alpha=.90)$ and validity has been supported by finding expected correlations with other career variables, such as exploration and planning (Patton, Bartrum, \& Creed, 2004). Alphas in the current study were .89 (adolescents) and .92 (parents).

Career planning. We used six career planning items from the short form of the Career Development Inventory, Australian version (CDI-A; Creed \& Patton, 2004; Lokan, 1984), which asked how much thought and planning had gone into the following: "Talking about career plans with an adult who knows something about me” and "Taking subjects that will help me decide what line of work to go into when I finish my education”. Responses were provided on a 4-point scale (1 = I have [my son/daughter has] not thought about this at all to $4=$ I have [my son/daughter has] made definite plans, and have [has] started to carry them out or know [s] what to do to carry them out). Alphas for short versions of the Career Planning scale have been sound ( $>$.80) and validity has been supported by finding positive correlations with career self-efficacy and career certainty (Creed \& Patton, 2004). Alphas were .76 (adolescents) and .87 (parents). 
Career exploration. This was measured using the 8-item Career Exploration subscale from the short form of the CDI-A (Creed \& Patton, 2004; Lokan, 1984), which tapped the sources of helpful information utilised by the adolescent, for example, “career teachers, career advisors, or school counsellors; other adults outside of school who know things and can be helpful; books, handbooks, or pamphlets with the information they need” (4-item response format: $1=$ Not yet asked to $4=$ Asked, and got a great deal of useful information). Creed and Patton (2004) reported alphas $>.80$ for the subscale and found expected correlations with career self-efficacy and certainty. Alphas with our samples were .78 (adolescents) and .85 (parents).

World-of-work knowledge. We used the 8-item subscale from the short form of the CDI-A (Creed \& Patton, 2004; Lokan, 1984), which tapped whether the adolescent had a good idea about occupational requirements, such as "What people really do on the job”, “The abilities needed for occupations", and "The education and training needed for occupations" (4-item response format: 1 = I hardly know anything to $4=I$ know a great deal). Past reliabilities have been good $(>.80)$ and the subscale has correlated with other career scales in the expected direction (Creed \& Patton, 2004). Our alphas were .92 (adolescents) and .94 (parents).

Career certainty. We used the 2-item career certainty subscale from the Career Decision Scale (Osipow, 1987), which assesses the degree of certainty regarding one’s career direction (4-point response format: $1=$ Exactly like $m e$ to $4=$ Not at all like $m e$ ). Past research has found sound internal reliability $(>$.80) and reported validity evidence (e.g., Hartman, Fuqua, \& Hartman, 1983). Alphas with our samples were .87 (adolescents) and .92 (parents).

\section{Procedure}

The study was conducted with the approval of the authors' ethics committee. The schools involved, parents, and adolescents all agreed to participate. Students were administered paper 
questionnaires by teachers in the classroom. Adolescents took home a questionnaire (and sealable, return envelope) for their parents.

\section{Results}

\section{Data Management}

We used latent variable analysis (AMOS V23; maximum likelihood estimation) to test the hypotheses. To meet the requirements of participants to parameters estimated (ideally 10:1; Bentler \& Chou, 1987), we created three multi-item composites or item parcels to represent each measure, except for the 2-item career certainty scale, where we used the observed variables. The procedure for creating the multi-item parcels is described in detail by Landis, Beal, and Tesluck (2000), but basically involves subjecting each scale to an exploratory factor analysis to generate factor loadings, allocating a mixture of items with high and low factor loadings to each parcel, and then summing the items within each parcel. Model fit was assessed using $\chi^{2}$ (with a sample size $>250$ and $<30$ observed variables, a non-significant $\chi^{2}$ is expected; Hair, Black, Babin, \& Anderson, 2010), the normed $\chi^{2}\left(\chi^{2} / \mathrm{df} ;<3.0\right.$ indicates an acceptable fit), Comparative Fit Index (CFI; > .92), and the Root Mean Square Error of Approximation (RMSEA; <.07).

We assessed a measurement model to determine if all latent variables could be represented by their parcels and/or observed variables, and then tested three structural models based on Figure 1. These were (a) adolescent-reported career planning, career exploration, world-of-work knowledge, and career certainty predicting adolescent vocational identity; (b) parent estimates of their child's career planning, career exploration, world-of-work knowledge, and career certainty predicting parent estimates of their child's vocational identity; and (c) both adolescent-reported and parent estimates of the child's career planning, career exploration, world-of-work knowledge, and career certainty predicting adolescentreported vocational identity. 


\section{Measurement Model}

The measurement model included 10 latent variables (adolescent- and parent-reports of the child's career planning, exploration, world-of-work knowledge, certainty, and vocational identity), which were all allowed to covary freely. The fit statistics for this were good, $\chi^{2}(301)=522.59, p<.001, \chi^{2} / \mathrm{df}=1.74$, CFI $=.98$, RMSEA $=.04$. All standardized regression weights were significant $(p<.001)$, ranging from .59 to .96 , and the correlations among the latent variables were similar to the zero-order correlations (see Table 1).

\section{Predicting Vocational Identity}

The fit statistics for the first structural model (adolescent-reported career planning, exploration, world-of-work knowledge, and certainty predicting adolescent-reported vocational identity) were good, $\chi^{2}(66)=70.34, p=.33, \chi^{2} / \mathrm{df}=1.07, \mathrm{CFI}=.99$, RMSEA $=$ .01. In this model, career planning $(\beta=.33, p<.001)$, world-of-work knowledge $(\beta=.20, p<$ $.001)$, and certainty $(\beta=.44, p<.001)$, but not exploration $(\beta=-.02, p=.73)$, were associated with vocational identity, accounting for $48 \%$ of the variance $\left(R^{2}=.69\right)$. When we repeated this analysis with the parent variables (parent estimates of child's career planning, exploration, world-of-work knowledge, and certainty predicting parent estimates of child's vocational identity), career planning $(\beta=.36, p<.001)$, exploration $(\beta=.15, p=.01)$, and certainty $(\beta=.52, p<.001)$, but not world-of-work knowledge $(\beta=.08, p=.19)$, were associated with vocational identity. These variables accounted for $38.2 \%$ of the variance $\left(R^{2}\right.$ $=.62)$.

For the final model (both adolescent-reported and parent estimates of the child's career planning, exploration, world-of-work knowledge, and certainty predicting adolescentreported vocational identity), the fit statistics were also good, $\chi^{2}(236)=376.88, p<.001$, $\chi^{2} / \mathrm{df}=1.60, \mathrm{CFI}=.98, \mathrm{RMSEA}=.04$. Of the eight predictors, only the adolescent variables of career planning $(\beta=.35, p<.001)$, world-of-work knowledge $(\beta=.20, p=.001)$, and 
certainty $(\beta=.41, p<.001)$ were associated with adolescent vocational identity. This analysis explained $49 \%$ of the variance $\left(R^{2}=.70\right)$ (see Figure 2$)$.

\section{Adolescent and Parent Congruence}

We examined the correlations between adolescent and parent scores to determine congruence between the two sources of career-related information (see Table 1 for correlations). All correlations were moderate (vocational identity $=.40$, career planning $=.46$, exploration $=.36$, world-of-work knowledge $=.32$, certainty $=.52$; all $p<.001$; the corresponding correlations for the latent variables were $.43, .46, .43, .34$, and .56 ), reflecting modest overlap in variance from the two sets of perceptions (variance overlap for observed variables ranged from $10 \%$ to $27 \%$; $12 \%$ to $31 \%$ for latent variables). This suggests meaningful but not substantial levels of agreement between parents and adolescents.

\section{Discussion}

Two objectives framed this study. The first was to assess the relationship between four career development tasks (exploration, planning, world-of-work knowledge, and certainty) and vocational identity in a sample of adolescents, as viewed by the adolescents themselves (H1a to H1d). The second objective was to assess congruence between parental and adolescent perceptions of adolescent career development tasks and vocational identity (H2a), assess whether the career development tasks were similarly related to vocational identity for parents and adolescents (H2b), and to assess whether parental perceptions of career development tasks helped explain adolescent vocational identity over and above the adolescents' own ratings (H2c). To our knowledge, this study is the first to assess these correlates and examine the congruence between parental and adolescent perceptions of career development tasks and vocational identity.

In addressing the first objective (H1), the latent variable analyses showed that, for adolescents, greater planning, world-of-work knowledge, and certainty, but not exploration, 
were associated with higher vocational identity (supporting H1b to H1d), explaining a substantial proportion of the variance (48\%). In addressing the second objective (H2), a second latent analysis showed that, for parents, planning, exploration, and certainty, but not world-of-work knowledge, were related to vocational identity, explaining meaningful, but less variance in vocational identity (38\%) then when adolescent ratings were assessed (partial support for H2b). These results suggest some overlap between adolescent and parent perceptions of the tasks associated with vocational identity. While other person and contextual variables (e.g., personality, values, career supports and barriers) need to be assessed in conjunction with these career tasks in order to provide a more comprehensive explanation of vocational identity (cf. Creed \& Hennessey, in press; Rogers et al., 2008), these findings augment previous research with adolescents (Creed \& Patton, 2003; Hirschi et al., 2011; Mortimer, Zimmer-Gembeck, Holmes, \& Shanahan, 2002) and are consistent with career construction and development theories (Flum \& Kaplan, 2006; Savickas, 2002; Super, 1990) that propose that healthy vocational identity relies on successful engagement in a variety of career development tasks.

Unexpectedly, career exploration was not associated with vocational identity for the adolescents. According to Nurmi's (1991) model of identity construction, adolescents first engage in exploration activities to identify their interests and goals and to acquire knowledge about future activities. Exploration is then followed by a construction and realisation of plans to achieve the set goals and to evaluate the future success of achieving them. Thus, exploration might be a more distal variable, and mediated by the other three career development variables. Future studies need to test temporal trajectories of these career development tasks and their relationships with vocational identity to further explore the role of career exploration. 
The second unexpected result was that world-of-work knowledge was not associated with vocational identity for parents. This might reflect differences in how adolescents and parents perceive occupational roles, the work environment in general, and vocational identity (Pelegrina et al., 2003). Future research could explore these differences, as this might influence the career advice and resources provided to parents who want to be involved directly in fostering their child's career development.

When further comparing the first two structural models, some additional similarities were demonstrated between parents and adolescents; both models identified career certainty and planning as the most important predictors of career identity (supporting H2b). While a positive relationship between career planning and various markers of vocational identity in young people has been found previously (e.g., Hirschi et al., 2011; Praskova, Creed, \& Hood, 2015; Turner \& Lapan, 2002), we provide evidence for the relationship between career certainty and vocational identity, which, although theoretically sound (Super, 1990), is scarce. Further, as our study tested four career development tasks in concert, we were better able to understand their unique contributions to explaining vocational identity.

Regarding congruence, parent and adolescent ratings on all variables were significantly correlated, supporting H2a. The correlations were moderate, indicating modest levels of parent-adolescent congruence in perceptions of career development tasks and vocational identity. While the literature indicates that parents play both direct and indirect roles in shaping adolescent career development and vocational identity to be in line with their own expectations for the adolescent (Jodl et al., 2001; Savickas, 2002; Hou \& Leung, 2011), our study demonstrates that parent and adolescent perceptions are not strongly overlapping. This suggests that while parents might be familiar with the career-related activities being undertaken by their adolescent, and have some understanding of their level of vocational identity, discussions between the parent and the child regarding career development tasks and 
vocational identity might not be as meaningful as they could be (see Levine \& Sutherland, 2013). This could be due to general changes in family dynamics during adolescence, which are often characterised by an adolescent's desire to gain greater autonomy and independence in making every-day as well as important decisions (Smetana \& Gaines, 1999; Yau \& Smetana, 2003).

Last, when the career development variables for both parents and adolescents were included in the model together to predict adolescent vocational identity (Figure 2), the parent variables did not explain significant variance in vocational identity over and above that of the adolescent scores (H2c not supported). This has important implications for future research and career counselling, as it suggests that asking adolescents about their career development tasks and vocational identity provides a useful evaluation of their status without having to also rely on evaluations of others as suggested by Stice and Barrera (1995). For the development of vocational identity, a largely internal, cognitive construct, adolescents are required to actively participate in various activities and behaviours and integrate these into their own developing cognitive structure. Thus, they are potentially better able to evaluate what they have done, are doing, and plan to do in the future. This interpretation is consistent with Pelegrina et al. (2003), who concluded that adolescents were better predictors of their academic success than their parents.

\section{Limitations and Future Directions}

While these findings provide useful insights into the relationship between career development tasks and vocational identity and how parents view their adolescent child's actions and level of identity, the study is not without limitations. Our sample was urban, and we had more adolescents and parents from private schools return a completed survey compared to those from public schools. It is plausible that private school parents have a higher level of education, higher expectations and a greater involvement in their adolescent's 
life, and therefore a greater influence on their career development (Hou \& Leung, 2011; Massey, Gebhardt, \& Garnefski, 2008; Wettersten et al., 2005). Future studies need to assess congruence in other contexts (e.g., with lower SES groups and in non-urban settings). Second, we assessed our model of vocational identity cross-sectionally. Future researchers should consider using longitudinal designs to examine the causal relationships among the variables, in particular, career exploration, as this variable may have a more indirect effect on vocational identity.

Last, we did not include person or contextual factors to test the influence of these variables in shaping adolescent career development and identity. Bandura, Barbaranelli, Caprara, and Pastorelli (2001), for example, argued that parental efficacy beliefs are able to promote adolescent efficacy and engagement in career pursuits, and further, that parental career-related self-efficacy beliefs based on their own achievements and aspirations might play an important part in their adolescent child's career choice. For instance, lower aspiring parents with a poorer sense of academic self-efficacy might discourage adolescent career pursuits in higher skilled jobs, and, thus, influence their child's career choice and development. Future research could assess the moderating effects of parent self-efficacy beliefs and expectations or other family factors (e.g., parent involvement and education, family dynamics, parenting style, and SES) in predicting adolescent vocational identity and congruence between parent and adolescent perceptions; this would contribute a greater understanding of the inter-relational processes involved in career development.

\section{Conclusions}

The present study contributed to the literature, first, by identifying which important adolescent career development tasks are linked to their vocational identity. Second, we were able to shed light on parental perceptions of these career development tasks and how they viewed adolescent vocational identity. Third, we found moderate relationships between 
adolescent and parent perceptions of career development tasks and vocational identity, suggesting meaningful but not substantial congruence of perceptions, and fourth, adolescents were better predictors of their vocational identity than their parents. In light of our findings, school educators and career counsellors should encourage adolescents to engage in activities that increase their knowledge about career development tasks as these should contribute to their vocational identity development, and should assist them with identifying occupational roles, planning for, and eventually making better career choices (Flum \& Blustein, 2006; Kroger, 2007; Skorikov \& Vondracek, 2011). Further, to take advantage of the impact and influence of the relationship between a parent and child (strength of relationship, depth of knowledge that a parent has of their child, amount of time parents spend with their child compared to teachers and school career counsellors, and because parents act as career role models; Kerpelman et al., 1997; Palmer \& Cochran, 1988; Skorikov \& Vondracek, 2011), educators and counsellors could design career educational programs that involve parents in career development processes, as this is likely to enhance parent understanding of their child's career development, greater congruence between parents and adolescents, potentially more involvement and support from parents, and better career and life outcomes for adolescents. 


\section{References}

Alliman-Brissett, A. E., Turner, S. L., \& Skovholt, T. M. (2004). Parent support and African American adolescents’ career self-efficacy. Professional School Counseling, 7, 124-132. Retrieved from http://www.jstor.org/stable/42732554

Austin, J.T., \& Vancouver, J.B. (1996). Goal constructs in psychology: Structure, process, and content. Psychological Bulletin, 120, 338-375. doi:10.1037/0033-2909.120.3.338

Bandura, A. (1991). Social cognitive theory of self-regulation. Organizational Behavior and Human Processes, 50, 248-287. doi:10.1016/0749-5978(91)90022-L

Bandura, A., Barbaranelli, C., Caprara, G. V., \& Pastorelli C. (2001). Self-efficacy beliefs as shapers of children's aspirations and career trajectories. Child Development, 72, 187-206. Retrieved from http://www.uky.edu/ eushe2/Bandura/Bandura2001CD.pdf

Bentler, P. M., \& Chou, C. (1987). Practical issues in structural modeling. Sociological Methods and Research, 16, 78-117. doi.org/10.1177/0049124187016001004

Blustein, D. L., Devenis, L. E., \& Kidney, B. A. (1989). Relationship between the identity formation process and career development. Journal of Counseling Psychology, 36, 196. doi.org/10.1037/0022-0167.36.2.196

Blustein, D. L., Ellis, M. V., \& Devenis, L. E. (1989). The development and validation of a two-dimensional model of the commitment to career choices process. Journal of Vocational Behavior, 35, 342-378. doi.org/10.1016/0001-8791(89)90034-1

Blustein, D. L., Pauling, M. L., DeMania, M. E., \& Faye, M. (1994). Relation between exploratory and choice factors and decisional progress. Journal of Vocational Behavior, 44, 75-90. doi.org/10.1006/jvbe.1994.1005

Constantine, M. G., Wallace, B. C., \& Kindaichi, M. M. (2005). Examining contextual factors in the career decision status of African American adolescents. Journal of Career Assessment, 13, 307-319. doi:10.1177/1069072705274960 
Creed, P. A., \& Hennessey, D. A. (in press). Evaluation of a goal orientation model of vocational identity. The Career Development Quarterly. Retrieved from http://onlinelibrary.wiley.com/journal/10.1002/(ISSN)2161-0045

Creed, P. A., \& Patton, W. (2003). Predicting two components of career maturity in school based adolescents. Journal of Career Development, 29, 277-290. doi:10.1177/089484530302900405

Creed, P. A., \& Patton, W. (2004). The development and validation of a short form of the Career Development Inventory - Australia. Australian Journal of Guidance and Counselling, 14, 125-138. Retrieved from http://search.informit.com.au.libraryproxy.griffith.edu.au

Creed, P. A., \& Patton, W. (2011). Developmental Issues in Career Maturity and Career Decision Status. The Career Development Quarterly, 49, 336-351. doi:10.1002/j.21610045.2001.tb00961.x

Danielsen, L. M., Lorem, A. E., \& Kroger, J. (2000). The impact of social context on the identity-formation process of Norwegian late adolescents. Youth \& Society, 31, 332-362. doi:10.1177/0044118X00031003004

Flum, H., \& Blustein, D.L. (2006). Reinvigorating the study of vocational exploration. Journal of Vocational Behavior, 56, 380-404. doi.10.1006/jvbe.2000.1721

Flum, H., \& Kaplan, A. (2006). Exploratory orientation as an educational goal. Educational Psychologist, 41, 99-110. doi:10.1207/s15326985ep4102_3

Gupta, A., Chong, S., \& Leong, F. T. L. (2015). Development and validation of the vocational identity measure. Journal of Career Assessment, 23, 79-90. doi:10.1177/1069072714523088

Gushue, G.V., \& Whitson, M. L. (2006). The relationship among support, ethnic identity, career decision self-efficacy, and outcome expectations in African American high school 
students: Applying social cognitive career theory. Journal of Career Development, 33, 112-124. doi:10.1177/0894845306293416

Hair, J. F., Black, W. C., Babin, B. J., \& Anderson, R. E. (2010). Multivariate data analysis. A global perspective (7th ed.). New Jersey, NJ: Prentice Hall.

Hartman, B., Fuqua, D., \& Hartman, P. (1983). The construct validity of the Career Decision Scale administered to high school students. Vocational Guidance Quarterly, 31, 250-258. doi:10.1002/j.2164-585X.1983.tb01543.x

Hirschi, A., Niles, S. G., \& Akos, P. (2011). Engagement in adolescent career preparation: Social support, personality and the development of choice decidedness and congruence. Journal of Adolescence, 34, 173-182. doi:10.1016/j.adolescence.2009.12.009

Holland, J. L. (1985). Making vocational choices: A theory of vocational personalities and work environments ( ${ }^{\text {nd }}$ ed.). Englewood Cliffs, NJ: Prentice Hall.

Holland, J. L., Johnston, J. A., \& Asama, N. F. (1993). The vocational identity scale: A diagnostic and treatment tool. Journal of Career Assessment, 1, 1-12. doi:10.1177/106907279300100102

Hou, Z., \& Leung, S. A. (2011). Vocational aspirations of Chinese high school students and their parents' expectations. Journal of Vocational Behavior, 79, 349-360. doi:10.1016/j.jvb.2011.05.008

Jodl, K. M., Michael, A., Malanchuk, O., Eccles, J. S., \& Sameroff, A. (2001). Parents’ roles in shaping early adolescents’ occupational aspirations. Child Development, 72, 12471266. doi:10.1111/1467-8624.00345

Julien, H. E. (1999). Barriers to adolescents’ information seeking for career decision making. Journal of the American Society for Information Science, 50, 38-48. doi:10.1002/(SICI)1097-4571(1999)50:1<38::AID-ASI6>3.0.CO;2-G 
Kerpelman, J. L., Pittman, J. F., \& Lamke, L. K. (1997). Toward a microprocess perspective on adolescent identity development: An identity control theory approach. Journal of Adolescent Research, 12, 325-346. doi:10.1177/0743554897123002

Ketterson, T. U., \& Blustein, D. L. Attachment relationships and the career exploration process. Career Development Quarterly, 46, 167-178. doi.org/10.1002/j.21610045.1997.tb01003.x

Kroger, J. (2007). Identity development (2nd ed.). Thousand Oaks, CA: Sage.

Landis, R. S., Beal, D. J., \& Tesluck, P. E. (2000). A comparison of approaches to forming composite measures in structural equation models. Organizational Research Methods, 3, 186-207. doi.org/10.1177/109442810032003

Levine, K. A., \& Sutherland, D. (2013). History repeats itself: Parental involvement in children's career exploration. Canadian Journal of Counselling and Psychotherapy, 47, 239-255. Retrieved from http://search.proquest.com

Lokan, J. (1984). Career Development Inventory Australia. Hawthorn, Victoria: Australian Council for Educational Research Limited.

Malmberg L.-E., Ehrman, J., \& Lithén, T. (2005). Adolescents’ and parents’ future beliefs. Journal of Adolescence, 28, 709-723. doi:10.1016/j.adolescence.2004.12.007

Massey, E. K., Gebhardt, W. A., \& Garnefski, N. (2008). Adolescent goal content and pursuit: A review of the literature from the past 16 years. Developmental Review, 28, 421-460. doi:10.1016/j.dr.2008.03.002

Meijers, F. (1998). The development of a career identity. International Journal for the Advancement of Counselling, 20, 191-207. doi.org/10.1023/A:1005399417256

Mortimer, J. T., Zimmer-Gembeck, M. J., Holmes, M., \& Shanahan, M. J. (2002). The process of occupational decision making: Patterns during the transition to adulthood. Journal of Vocational Behavior, 61, 439-465. doi:10.1006/jvbe.2002.1885 
Mu, X. (1998). High school experience and career maturity in young adulthood. In Paper presented at the 24th International Congress of Applied Psychology, August, San Francisco.

Nurmi, J.-E. (1991). How do adolescents see their future? A review of the development of future orientation and planning. Developmental Review, 11, 1-59. doi:10.1016/02732297(91)90002-6

Osipow, S. H. (1987). Career Decision Scale Manual. Odessa, FL: Psych. Assessment Resources Inc.

Otto, L. (2000). Youth perspectives on parental career influence. Journal of Career Development., 27, 111-118. doi:10.1177/089484530002700205

Patton, W., Bartrum, \& Creed, P. A. (2004). Gender differences for optimism, self-esteem, expectations and goals in predicting career planning and exploration. International Journal for Educational and Vocational Guidance, 4, 1-17. doi:10.1007/s10775-005$1745-\mathrm{z}$

Palmer, S., \& Cochran, L. (1988). Parents as agents of career development. Journal of Counseling Psychology, 35, 71-76. doi.org/10.1037/0022-0167.35.1.71

Pelegrina, S. García-Linares, \& Casanova, P. F. (2003). Adolescents and their parents’ perceptions about parenting characteristics. Journal of Adolescence, 26, 651-665. doi:10.1016/S0140-1971(03)00062-9

Phillips, S.D., \& Blustein, D.L. (1994). Readiness for career choices. The Career Development Quarterly, 43, 63-71. Retrieved from http://search.proquest.com.

Porfeli, E.J., Lee, B., \& Vondracek, F.W. (2013). Identity development and careers in adolescents and emerging adults. In W.B. Walsh, M.L. Savickas, \& P. Hartung (Eds.), Handbook of vocational psychology (pp. 133-154). New York, NY: Routledge Press. 
Praskova, A., Creed, P. A., \& Hood, M. (2015). Career identity and the complex mediating relationships between career preparatory actions and career progress markers. Journal of Vocational Behavior, 87, 145-153. doi:10.1016/j.jvb.2015.01.001

Robitschek, C., \& Cook, S.W. (1999). The influence of personal growth initiative and coping styles on career exploration and vocational identity. Journal of Vocational Behavior, 54, 127-141. doi:10.1006/jvbe.1998.1650

Rogers, M. E., \& Creed, P. A. (2011). A longitudinal examination of adolescent career planning and exploration using a social cognitive career theory framework. Journal of Adolescence, 34, 163-172

Rogers, M. E., Creed, P. A., \& Glendon, A. I. (2008). The role of personality in adolescent career planning and exploration: A social cognitive perspective. Journal of Vocational Behavior, 73, 132-142.

Rojewski, J. W. (1994). Predicting career maturity attitudes in rural economically disadvantaged youth. Journal of Career Development, 2, 49-61. Retrieved from http://link.springer.com/article/10.1007\%2FBF02107103

Savickas, M.L. (1999). The transition from school to work: A developmental perspective. The Career Development Quarterly, 4, 326-336. doi:10.1002/j.21610045.1999.tb00741.x

Savickas, M.L. (2002). Career construction. In D. Brown \& Associate (Eds.), Career choice and development ( $4^{\text {th }}$ ed., pp. 149-205). San Francisco, CA: Jossey-Bass.

Skorikov, V.B., \& Vondracek, F.W. (2011). Occupational identity. In S.J. Schwartz, K. Luyckx, \& V.L. Vignoles (Eds.), Handbook of identity theory and research (pp. 693-714). New York, NY: Springer. doi.10.1007/978-1-4419-7988-9_29 
Smetana, J., \& Gaines, C. (1999). Adolescent-parent conflict in middle-class African American families. Child Development, 70, 1447-1463. Retrieved from http://onlinelibrary.wiley.com/doi/10.1111/1467-8624.00105/pdf

Super, D. (1990). A life span, life-space approach to career development. In D. Brown \& L. Brooks (Eds.), Career choice and development (2nd ed., pp. 197-261). San Francisco, CA: Jossey-Bass.

Staff, J., Harris, A., Sabates, R. \& Briddell, L. (2010). Uncertainty in early occupational aspirations. Social Forces, 89, 659-683.doi:10.1353/sof.2010.0088

Stice, E., \& Barrera, M. (1995). A longitudinal examination of the reciprocal relations between perceived parenting and adolescents’ substance use and externalizing behavior. Developmental Psychology, 31, 322-334. doi:10.1037/0012-1649.31.2.322

Trede, F. (2012). Role of work-integrated learning in developing professionalism and professional identity. Asia-Pacific Journal of Cooperative Education 13,159-167. Retrieved from http://www.apjce.org/files/APJCE_13_3_159_167.pdf

Tucker, C. J., Barber, B. L., \& Eccles, J. S. (2001). Advice about life plans from mothers, fathers, and siblings in always-married and divorced families during late adolescence. Journal of Youth and Adolescence, 30, 729-747. Retrieved from http://rcgd.isr.umich.edu/garp/articles/eccles01l.pdf

Turner, S. \& Lapan, R. T. (2002). Career self-efficacy and perceptions of parent support in adolescent career development. The Career Development Quarterly, 51, 44-55. doi:10.1002/j.2161-0045.2002.tb00591.x

Vondracek, F. W., Lerner, R. M., Schulenberg, J. E. (1986). Career development: A life-span developmental approach. Hillsdale, NJ: Erlbaum.

Vondracek, F.W., \& Skorikov, V.B. (1997). Leisure, school, and work activity preferences and their role in vocational identity development. The Career Development 
Quarterly, 45, 322-340. doi:10.1002/j.2161-0045.1997.tb00537.x

Yau, J., \& Smetana, J.G. (2003). Adolescent-parent conflict among Chinese Adolescents in Hong Kong and Shenzhen: A comparison of youth in two cultural contexts. International Journal of Behavioral Development, 27, 201-211.doi: 10.1080/01650250244000209

Wettersten, K. B., Guilmino, A., Herrick, C. G., Hunter, P. J., Kim, G.Y., Jagow, D., Beecher, T., Faul, K., Baker, A. A., Rudolph, S. E., Ellenbecker, K., \& McCormick, J. (2005). Predicting educational and vocational attitudes among rural high school students. Journal of Counseling Psychology, 52 658-663. doi:10.1037/0022-0167.52.4.658

Whiston, S. C., \& Keller, B. K. (2004). The influences of the family of origin on career development: A review and analysis. The Counseling Psychologist, 32, 493-568. doi:10.1177/0011000004265660

Witko, K., Barnes, K. B., Magnusson, K., \& Bardick, A. D. (2005). Senior high school career planning: What students want. Journal of Educational Enquiry, 6, 34-49. Retrieved from http://www.ojs.unisa.edu.au/index.php/EDEQ/article/view/500/369

Young, R. A., Friesen, J. D., \& Dillabough, J. M. (1991). Personal constructions parental influence related to career development. Canadian Journal of Counselling, 25, 183-190. Retrieved from http://cjc.synergiesprairies.ca/cjc/index.php/rcc/article/ viewFile/1115/1003

Young, R. A., Valach, L., Paseluikho, M. A., Dover, C., Matthes, G. E., Paproski, D. L., \& Sankey, A. M. (1997). The joint action of parents and adolescents in conversation about career. Career Development Quarterly 46, 72-86. doi:org/10.1002/j.21610045.1997.tb00693.x

Zikic, J., \& Hall, D.T. (2009). Toward a more complex view of career exploration. The Career Development Quarterly, 58, 181-191. doi:10.1002/j.2161-0045. 2009.tb00055.x 
Zimmer-Gembeck, M. J., \& Mortimer, J. T. (2006). Adolescent work, vocational development, and education. Review of Educational Research, 76, 537-566. doi:10.3102/00346543076004537 


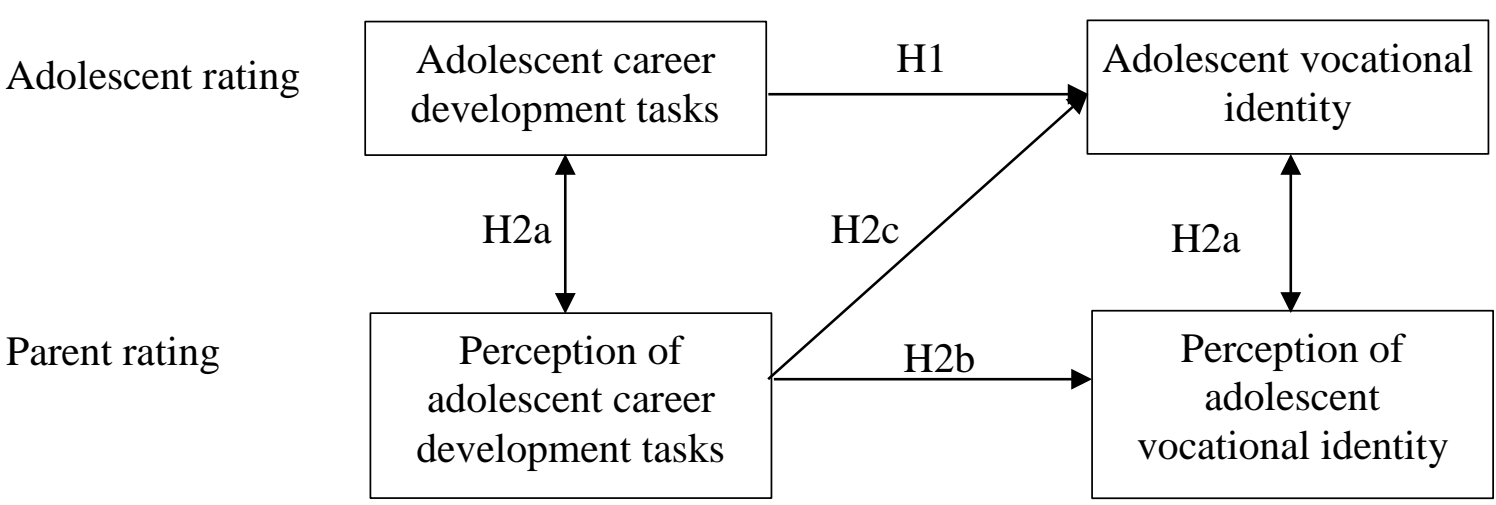

Figure 1. Hypothesised relationships between parent and adolescent perceptions of the adolescents' career development variables and vocational identity 


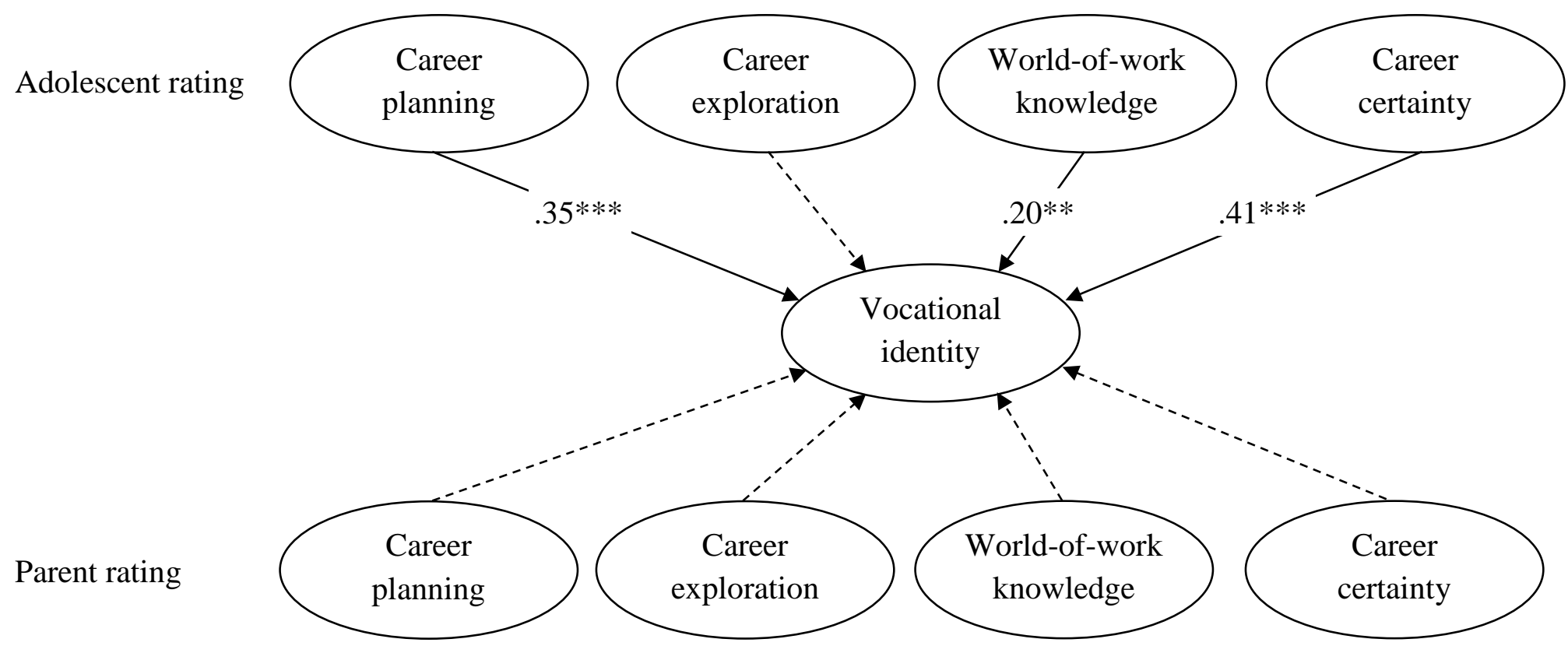

Figure 2. Adolescent-reported and parent estimates of the child's career planning, career exploration, world-of-work knowledge, and career certainty predicting adolescent-reported vocational identity; standardised beta weights reported. 
Table 1

Summary Data and Correlations among Variables for Adolescent and Parent Samples $(N=415$ for both group

\begin{tabular}{|c|c|c|c|c|c|c|c|c|c|c|c|c|c|c|}
\hline Variables & $M$ & $S D$ & 1 & 2 & 3 & 4 & 5 & 6 & 7 & 8 & 9 & 10 & 11 & 12 \\
\hline 1. Identity (A) & 18.20 & 3.67 & - & $.56^{* * *}$ & $.42 * * *$ & $.61 * * *$ & $.67 * * *$ & $.40 * * *$ & $.36 * * *$ & $.25 * * *$ & $.34 * * *$ & $.45 * * *$ & -.08 & .06 \\
\hline 2. Planning (A) & 18.18 & 3.38 & $.72 * * *$ & - & $.53 * * *$ & $.50 * * *$ & $.51 * * *$ & $.34 * * *$ & $.46 * * *$ & $.33 * * *$ & $.36 * * *$ & $.37 * * *$ & -.01 & -.09 \\
\hline 3. Exploration (A) & 16.05 & 6.58 & $.53 * * *$ & $.72 * * *$ & - & $.47 * * *$ & $.36 * * *$ & $.24 * * *$ & $.32 * * *$ & $.36 * * *$ & $.28 * * *$ & $.28 * * *$ & .09 & -.03 \\
\hline 4. Work knowledge (A) & 27.43 & 7.19 & $.67 * * *$ & $.62 * * *$ & $.57 * * *$ & - & $.57 * * *$ & $.26 * * *$ & $.28 * * *$ & $.21 * * *$ & $.32 * * *$ & $.29 * * *$ & -.02 & $.11^{*}$ \\
\hline 5. Certainty (A) & 5.39 & 1.75 & $.77 * * *$ & $.64 * * *$ & $.47 * * *$ & $.64 * * *$ & - & $.43 * * *$ & $.40 * * *$ & $.30 * * *$ & $.37 * * *$ & $.52 * * *$ & .06 & .09 \\
\hline 6. Identity (P) & 17.95 & 3.86 & $.43^{* * *}$ & $.40 * * *$ & $.28 * * *$ & $.27 * * *$ & $.45^{* * *}$ & - & $.63 * * *$ & $.38 * * *$ & $.59 * * *$ & $.71^{* * *}$ & .05 & .01 \\
\hline 7. Planning (P) & 18.25 & 4.22 & $.41^{* * *}$ & $.46 * * *$ & $.42 * * *$ & $.32 * * *$ & $.46^{* * *}$ & $.67 * * *$ & - & $.61 * * *$ & $.69 * * *$ & $.64 * * *$ & $.12^{*}$ & -.07 \\
\hline 8. Exploration (P) & 15.69 & 7.17 & $.28 * * *$ & $.40 * * *$ & $.43 * * *$ & $.23 * * *$ & $.33 * * *$ & $.42 * * *$ & $.72 * * *$ & - & $.62 * * *$ & $.45^{* * *}$ & $.18 * * *$ & -.01 \\
\hline 9. Work knowledge (P) & 23.33 & 7.66 & $.37 * * *$ & $.41^{* * *}$ & $.34 * * *$ & $.34 * * *$ & $.39 * * *$ & $.59 * * *$ & $.74^{* * *}$ & $.67 * * *$ & - & $.64^{* * *}$ & $.13^{* *}$ & .04 \\
\hline 10. Certainty (P) & 5.42 & 1.89 & $.49 * * *$ & $.45^{* * *}$ & $.36 * * *$ & $.32 * * *$ & $.56^{* * *}$ & $.75 * * *$ & $.69 * * *$ & $.50 * * *$ & $.66^{* * *}$ & - & .08 & .04 \\
\hline 11. Age (A) & 16.28 & 0.89 & - & - & - & - & - & - & - & - & - & - & - & $-.12^{*}$ \\
\hline 12. Gender (A) & - & - & - & - & - & - & - & - & - & - & - & - & - & - \\
\hline
\end{tabular}

Note: $(\mathrm{A})$ = Adolescent, $(\mathrm{P})$ = Parent. Bivariate correlations reported above the diagonal; correlations among latent variables reported below the diagonal. Coefficients in bold indicate congruency between adolescents and parents on career variables.

$*=p<.05 ; * *=p<.01 ; * * *=p<.001$ 